\section{HSE}

Historia Social y de la Educación

Social and Education History
Hipatia Press

www.hipatiapress.com

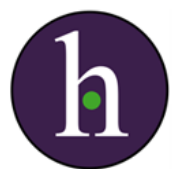

Instructions for authors, subscriptions and further details:

http://hse.hipatiapress.com

\title{
Contributions of Freire's Theory to Dialogic Education
}

Maria del Mar Ramis ${ }^{1}$

1) Universitat de Barcelona (España)

Date of publication: October $23^{\text {th }}, 2018$

Edition period: October 2018 - February 2019

To cite this article: Ramis, M.M. (2018). Contributions of Freire's Theory to Dialogic Education. Social and Education History, 7(3), 277-299. doi: http://dx.doi.org/10.17583/hse.2018.3749

To link this article: http://dx.doi.org/10.17583/hse.2018.3749

\section{PLEASE SCROLL DOWN FOR ARTICLE}

The terms and conditions of use are related to the Open Journal System and to Creative Commons Attribution License (CCAL). 


\section{Contribution of Freire's Theory to Dialogic Education}

Maria del Mar Ramis

Universitat de Barcelona

\section{Abstract}

The present article discusses how Paulo Freire was ahead of his time with his theoretical contributions by reflecting on the author's groundbreaking insights, particularly those developed in his Pedagogy of the oppressed. To do so, the paper first introduces his Theory of Dialogical Action and the premises that explain how it established the theoretical grounds for some of the most relevant theoretical works in the Social Sciences such as Habermas' Theory of the Communicative Action developed more than a decade after Freire's work. The second part of the paper further explores the influence of the premises of the Dialogic Education, by reviewing the theoretical foundations of other major theoretical works and practical experiences that building on Freire's work and the centrality of dialogue in the educational process continue enabling the creation of future through transformative educational experiences. In so doing, the impact that the legacy of one of the most relevant authors in the history of education has had upon most relevant theoretical conceptualisations as well as a successful practical key experience is further explained.

Keywords: Freire, Pedagogy of the Oppressed, Dialogic Action, Communicative Action, Dialogic learning 


\section{Contribuciones de la Teoría de Freire a la Educación Dialógica}

Maria del Mar Ramis

Universitat de Barcelona

\section{Resumen}

El presente artículo presenta cómo Paulo Freire fue un autor adelantado a su tiempo a través de sus contribuciones teóricas, basándose en la reflexión sobre el pensamiento precursor de este autor, especialmente presente en su obra Pedagogía del Oprimido. Para ello, el presente artículo introduce su Teoría de la Acción Dialógica y las premisas que explican cómo se establecen las bases teóricas de algunas de las obras posteriores más relevantes de la teoría en Ciencias Sociales como la Teoría de la Acción Comunicativa de Habermas desarrollada más de una década después de la aparición de este trabajo de Freire. La segunda parte de este artículo explora más en detalles la influencia de las premisas de la educación dialógica, revisando las bases teóricas de otras obras relevantes en Ciencias Sociales, así como experiencias prácticas que sobre las bases del trabajo de Freire y la centralidad del diálogo en el proceso educativo continúan posibilitando la creación de futuro a través de experiencias educativas transformadoras. Así, se abunda en el impacto que el legado de uno de los autores más relevantes en la historia de la educación tiene tanto sobre las conceptualizaciones teóricas más relevantes como sobre las experiencias prácticas de más éxito.

Palabras clave: Freire, Pedagogía del Oprimido, Acción Dialógica, Acción Comunicativa, Aprendizaje Dialógico 
I engage in dialogue not necessarily because I like the other person. I engage in dialogue because I recognize the social and not merely the individualistic in the process of knowing ${ }^{l}$

Many are the contributions that we have received from the work of Paulo Freire and the relevance they have had for the understanding of the process of education and its potential impact upon society are widely recognized. It is also true that these contributions have not always been given the visibility they have today. Rather, clear attempts have been made to omit its significant message, the tool it becomes for the educational process, particularly of the most vulnerable communities. Freire's work at the end of the 60's was pioneering in the propositions it made about the centrality of dialogue in its meaning of intersubjectivity as communication between people but also as a means of dialogue with reality, establishing the link between theory and practice that, between consciousness and nature, subject and object (Botey and Flecha, 1998). Building on this framework, this article discusses some of the contributions of Paulo Freire, whose legacy has transformed the way education is understood in diverse fields and the impact it has in society and the processes of social transformation. Importantly though, the paper also explores how Freire was ahead of his time with the groundbreaking insights made in his theoretical developments, particularly in the Pedagogy of the oppressed (Freire, 2018), which were years later central in social sciences and humanities theoretical works.

This paper has two major sections. In the first one, Freire's insights on the importance of dialogue and its constituents are explored. The Theory of Dialogical Action (TDA) is introduced reviewing some of the most significant contributions about how this dialogue needs to be, the role of the participants in it, their relationship and the interaction that is necessary. In so doing, a link between Freire's pioneer work and the later theoretical developments of some of the most important social scientists of our time and their momentous theoretical works such as with Jürgen Habermas and his Theory of the Communicative Action (Habermas, 1984; 1987) is shown shedding light upon the fact that Freire was ahead of its time and developed a theory which has been one of the most influential works in education and other social sciences of our time.

In the second part of this paper, the influence of the Dialogic Education is explored by reviewing other theoretical works and practical experiences that 


\section{Ramis - Freire's Dialogic Education}

have been created building on Freire's theory and the centrality of dialogue. In so doing, these theories and practices are generating transformative educational experiences fostering the joint action of all agents interacting in the educational process and creating opportunities for many children and adults, end-users and researchers, which are in debt with the legacy of the Brazilian author.

\section{Theory of the Dialogical Action: a Theory of Education that Creates}

\section{Future}

In Freire's work, dialogue and the power of the word are central elements featuring the search of the conditions that will allow the oppressed to overcome their situation of oppression (Freire, 2005). Human agency for Freire is a powerful tool to reverse the situation of social exclusion that some human groups face and prove of this are many of his statements regarding the fact that we are beings of transformation and not of adaptation (Freire, 1997). The work of Paulo Freire has been essential for understanding the critical role of giving the voice to those who have traditionally been excluded from contexts of dialogue and participation. Granting a major role to these individuals as critical agents is a form of radicalizing democracy which has inspired and still inspires theories and practices that are developed in different corners of the world for the overcoming of the given situation that the structures at work maintain. Freire's analyses question the limited and limiting reproductionist theories by proving that when given the power of word and dialogue, people are able of change, to deeply transform the structures of oppression they find themselves in. Indeed, Freire's trust in the power of the oppressed goes on to state that only power that springs from the weakness of the oppressed will be sufficiently strong to free both [the oppressors as well as the oppressed] (Freire, 2005, p. 44). For this author the power of the word and dialogue lies in the commitment to transform as only the words that come from engagement into transformation are able to denounce a situation of oppression. As he puts it:

When a word is deprived of its dimension of action, reflection automatically suffers as well; and the word is transformed into idle chatter, into verbalism, into an alienated and alienating "blah". It 
becomes an empty word, one which cannot denounce the world for denunciation is impossible without a commitment to transform and there is no transformation without action (Freire, 2018, p. 87).

Dialogue in Freire overcomes the constructivist conception limiting the process of education to what happens between the educator and the student who jointly construct meaning within the boundaries of the classroom. His proposal of dialogue extends the process of learning and education to the whole community as builder of reality (Flecha and Puigvert, 1998). It is this feature of jointly building reality and thus creating future that is most relevant in the history of education and the educational proposals that have drawn from it. Realities that where inexistent and even unimagined are thus considered, discussed and made possible through agents engaging in the dialogical action that Freire developed. The accuracy and rigor with which he defined his theory based on many years of scientific inquiry and social transformation in Brazil is a legacy to which educators but also social scientists from different disciplines are in depth with.

As it has pointed out in the literature, one of the problems of Freire's theory is that it has oftentimes been misinterpreted. For instance, it has been mistakenly said that his theory is naif - while it has supporting evidence to proving the statements done through the hundreds of cases developed in the communities he worked with - or that it is not rigorous because it seeks transformation - while most of social scientists, not to mention other sciences, seek indeed to generate an improvement with their work, in order to contribute to societal progress and the advance of the conditions in which citizens live (Flecha, Soler-Gallart and Sordé, 2015).

Yet some other misinterpretations understood the dialogic action in Freire as a method, a sort of technique that could be applied stripping of it "the essence of his radical pedagogical proposals that go beyond the classroom boundaries and effect significant changes in society" (Macedo in Freire, 2005, p. 17). The pedagogy of Freire seeks to understand the reality in which the dialogue occurs where the actors jointly share a process of teaching and learning about the world that allows for the overcoming of a particular situation of inequality. In other words, mistaken interpretations of Freire's work disregard the fact that for him, dialogue is not a mere conversation but rather it is the process through which different people coordinate the action 


\section{Ramis - Freire's Dialogic Education}

in order to achieve a common goal (Flecha, 2004). Therefore, this dialogue cannot be just a method, void of the commitment to understand the object of study and theorize about what happens in the very process of dialogue. Before we come back to this commitment, we recall a moment of Freire's work and life which facilitated the impact of his work on the world.

Following the impact that the publication of his work had, the University of Harvard in 1969 offered Freire - who had been imprisoned in Brazil after the military coup in 1964 and was living in exile- a visiting professorship that had a profound impact on the widespread of his theory in the world. Those where difficult years in the US and worldwide after the tragic events of the assassinations in 1968 of both Martin Luther King in April and Robert Kennedy in June, which had also followed the earlier murder of John F. Kennedy in November 1963. M.L. King's life struggle for equality and the hope for it becoming a reality had been expressed and shared by millions through his "I have a dream" speech delivered during the March on Washington for Jobs and Freedom in August 1963 to 250,000 attendees, a major landmark in the movement for civil rights in the US. Many citizens had been inspired by his dream worldwide, and this inspiration and hope were threatened by the despair that followed the tragic events in the late 60 's.

It is therefore that Freire's theory and works where a new source of inspiration for many educators and social scientists in the US and beyond. He had already published both Education as a practice of freedom (1967) and Pedagogy of the oppressed (1968) and had achieved outstanding results with his theory in his homeland, namely: following his work and method 300 sugarcane workers had learned to read and write in just 45 days.

Freire was showing that with scientific rigor as well as with hope better results were enabled in education, especially ones which had a great impact in many lives. The work of Freire allowed thousands of people in Brazil to become literate and with that, to have access to a better life and also to be able to exert their right to vote - literacy was a requested condition for voting in the presidential elections in the country as stated in the country's 1891 Constitution (Martínez-Fritscher, Musacchio and Viarengo, 2010). This made of literacy education a very important task in Brazil especially considering the high rates of illiteracy that the country had with a rate of 60 percent literate population in 1960 (Roser and Ortiz-Ospina, 2018) and 


\section{HSE - Social and Education History, 7(3) 283}

therefore the work of Freire was especially relevant, and a source of opportunity.

The evidence of the impact that his theory and work achieved through the Popular Culture Movement and the circles of culture sent a message to the world about the power of education and literacy to change the conditions in which people lived. Freire's theory but also the evidence of its success was a renewed source for hope, a new and true way to "keeping one's dream alive". And his message was very welcome in Harvard and, from there, also in the world. Freire's was not only allowing hope for the future but, also, he was creating a future that had not yet existed since. Through his joining the scientific rigor of his systematic work with literacy programmes and his commitment to hope and with the most underprivileged communities in his country, Freire became a world reference and can be counted among the most influential educationists in history. He was showing the world with his work in the cultural circles in slums in Brazil that a particular understanding of dialogue which enables people to coordinate their actions on the basis of a shared understanding of reality, promotes the possibility of changing the reality that is being shared. His Theory of Dialogic Action developed in the 60 's has become not only a landmark in education but also a major influence in the turn that social sciences experienced since the last decades of the $20^{\text {th }}$ century.

\section{Dialogue in Freire's Theory of Dialogic Action}

One of the most relevant ideas that one comes across in Freire's work as it is presented in his Pedagogy of the oppressed (2005) is the need for dialogical action to be completely void of any type of violence, dogmatism or authoritarianism. The education he proposes is a liberating one, an act of cognition understood as a learning situation in which there is an intermediation between different actors all of which are teachers and learners at the same time. Therefore, in a process in which all actors are set on an egalitarian plain, arguments based on "authority" of one over the others, are no longer valid. As Freire understands it, authority must be on the side of freedom and not against it (Freire, 2018, p.80).

In dialogical action, students cease to be passive recipients of information to become active agents of critical inquiry together with the teachers, and 


\section{Ramis - Freire's Dialogic Education}

together they "read" the world in a way that allows for students to understand processes affecting them. We will elaborate on this below.

In antidialogical action, on the contrary, the desire -or as Freire highlights- the necessity of conquest is always present as one of the agents (the oppressor) has the need of subjugating the other agent (the oppressed) in an act of manipulation to try to conform the other to one's objectives. This manipulation is grounded on power claims, where authority is not on the side of freedom.

The essence of this dialogical action with the centrality of dialogue as a means of transformation of reality has been incorporated by the most relevant social scientists of the $20^{\text {th }}$ century such as Jürgen Habermas or Ulrich Beck (Beck and Beck-Gernsheim, 1995; Habermas, 1984). Following the premises that Freire developed, the need of incorporating dialogue in all spheres of life has become central in contemporary social sciences, especially since information society has seen an increase in pluralism, uncertainty, diversity and risk where traditional authorities have been questioned by a diversity of voices which have now taken a more active and present role.

In the same way that the authority of the teacher based solely on his or her position of power is questioned in Freire's problem-posing education, so do other prominent social scientists propose the de-monopolisation of expert knowledge (Beck, Giddens and Lash, 1994) also based on everyone's capacity of language and action (Habermas, 1984). More so, Freire highlights that the desire and need of conquest -exertion of power- is present in antidialogical education and indicates the manipulation through which elites try to continue dominating the masses and having them conform to their own objectives. The "power claims" that these oppressing elites have been exerting for centuries through an antidialogical education have been unveiled and denounced by liberating education, one that poses dialogue and not power- at the centre of the action. In the same line, Habermas states the need to replace the "power claims" which are present in everyday relations at all levels private and public, by "validity claims" which by allowing for a kind of dialogue that gives priority to the truth of utterances, including the use of a language that does not mislead the speakers in any way such as he does in his analysis of illocutionary or perlocutionary effects of language (Habermas, 1984). 
Through his theory of dialogical action Freire sought the creation of -and actually contributed to create- the ideal conditions between the actors that would allow them to change that what is oppressing them. In problemposing education his theory of dialogical action is developed, where dialogue is seen as the indispensable tool to reveal truth, the world, the actors' (students and teachers) reality, through cognition. As he puts it in his Pedagogy of the oppressed "the role of the problem-posing educator is to create together with the students, the conditions under which knowledge at the level of the doxa is superseded at the level of true knowledge, at the level of the logos" (p. 81). Through this type of dialogue and the reflection that it entails, people "increase the scope of their perception" becoming aware of situations and conditions in their lives which they were not previously aware of. And, it is through "knowing" the world through this dialogue that action is enabled; not any action but one which will allow to create the conditions for transformation. Both reflection and action in close interaction are the necessary conditions for dialogical action and if one of them is prevented the word "becomes an empty word, one which cannot denounce the world for denunciation is impossible without commitment to transform, and there is no transformation without action" (p. 87). In so doing, Freire not only defines the conditions that are necessary for this enabling dialogue to take place but also the threats posed to it, and the violence these threats imply when individuals are prevented from engaging into the process of inquiry that dialogical action entails, or where individuals are "alienated from their own decision-making" (p.85).

For Freire to transform the world through saying the true word is not a right of only some privileged individuals but a right of everyone and it is therefore that the conditions for saying the true word need to be created for all. In the same line, Habermas (1984) included this idea in his Theory of Communicative Action as he admits that when behavior is described in terms of communicative action, and all actors are ready to do so on equal terms, any privileged position as observers is lost and then participation is necessary in the process of reaching an understanding:

But as soon as we equip the actors with this capability, we lose our privileged position as an observer in relation to the object domain. (...) We find ourselves forced to participate, in a performative 
attitude, in the process of reaching understanding. We thereby expose our interpretation in principle to the same critique to which communicative agents must mutually expose their interpretations (Habermas, 1984, p. 119).

It is through this egalitarian dialogue that the necessary act of conscientizaçao through which people go from objects to subjects of history takes place as Freire describes it. A process that is the result of reading the word and the world, in interaction between the different actors.

\section{Interaction}

Freire develops dialogical action delving into the relevance of interaction among the actors and between the actors and the world, and how this interaction facilitates the possibility of action upon the world. To do so, he highlights the importance of several elements such as the relation between the speakers and the means they need to put at work in order to decode the world. We go into these more in detail as they are also key elements that have been further developed in the educational theories and practices that we will review in the second section of this paper.

The understanding of the world needs to count on the dialogue between actors which is never an imposition of one's truth upon the others'. As Freire puts it, it cannot be the act of one person "depositing" ideas on another one but rather a point of encounter where action and reflection of the speakers who interact are united into a joint understanding of the world, and where no-one speaks on behalf of others, nor passively "consumes" other persons' ideas.

This interaction will at times facilitate the action of individuals who, in certain situations of alienation might not be having the power to do so. In an educational situation, it is the task of the educator or the person that plays its role to facilitate the critical interaction that can lead to empower individuals to regain their natural power of creation and transformation. To this end thus, it is relevant to understand the processes through which individuals are enabled to coding and decoding a particular situation through interaction (of individuals and them with the object or situation they are in). 
In problem-posing education, for an individual to change a limitsituation in which he or she might be, first of all there is the need to apprehend it in a critical way, in all its dimension and depth. This for Freire implies the need for individuals of having a total vision of the context so that they can eventually isolate fundamental components of it and through the analysis of these elements' interaction, reach a more accurate insight of the whole. This critical way of thinking about one's own world is what is entailed by the process of conscientizaçao, when a new critical attitude is enabled toward a limit-situation, rectifying the perception of reality.

In education, this is done through bringing a concrete situation to the abstract, coding it in order to facilitate a dialectical interaction between the concrete and the abstract. Decoding will involve a movement of thought from the abstract to the concrete, from the part to the whole and back. Through this process the individuals need to recognize themselves as part of these situations, interacting together in it with other subjects and in this process, a situation which was first not apprehended gets to be understood by the very subjects who are the protagonists, acquiring new meaning, as explained below:

When an individual is presented with a coded existential situation (a sketch or photograph which leads by abstraction to the concrete-ness of existential reality), his tendency is to "split" that coded situation. In the process of decoding, this separation corresponds to the stage we call the "description of the situation," and facilitates the discovery of the interaction among the parts of the disjoined whole. This whole (the coded situation), which previously had been only diffusely apprehended, begins to acquire meaning as thought flows back to it from the various dimensions. Since, however, the coding is the representation of an existential situation, the decoder tends to take the step from the representation to the very concrete situation in which and with which she finds herself. It is thus possible to explain conceptually why individuals begin to behave differently with regard to objective reality, once that reality has ceased to look. (Freire, 2005, p. 105) 
Freire's theory of dialogical action is one that creates future by enabling the involved actors to be aware of the world and thus enabled to change it, and therefore shows how Freire was a scientist ahead of his time. The analysis of the conditions of dialogue which allow for transformation and which are central in present day social and human sciences are present in his work, 12 years before authors like Habermas elaborated their own theories about the centrality of dialogue in 1984, and how this results of -and also enables- current and future socio-political transformations.

Finally, it is necessary to mention one of the elements that are crucial in Freire's work and his proposal for a dialogical action: hope; the hope that enables to "attempt to overcome the limit-situations". Hope without which no the expectation nor hope exists, and the dialogue is sterile and will not bring results to the efforts. For Freire the capacity of action when lead by hope empowers humans to be creators of new realities including social institutions, ideas and concepts. We explore some of these below.

\section{Dialogic Education: Theories and Practices}

Since Freire's work has been spread worldwide, dialogical education has not ceased to grow inspiring new theories and also practices, which are enabling the creation of future for many individuals, and particularly those finding themselves in challenging situations. This includes the theory of The Culture of Education of Jerome Bruner (1996), one of the most relevant educational psychologists in the world ranked as the most cited psychologist in the $20^{\text {th }}$ century, or dialogic learning (Flecha, 2000; Aubert et al. 2008) and also educational practices like Schools as Learning Communities or the Dialogic Literary Gatherings which are transforming the contexts through the participation of the communities and also creating new future for all actors involved. These have been developed on the grounds of Freire's legacy, with the absence of any sort of violence, the dialogue as a central element allowing for the overcoming of limit-situations and the focus on interaction as central elements.

\section{Freire's Legacy in Dialogic Education, its Impact in Theory and Practices}


Jerome Bruner's relevance in educational psychology is undisputed. Although his contributions to cognitive and developmental psychology, as well as to language development are significant, it is his work in cognitive learning theory and the focus on culture and context that are most relevant in our analysis. Bruner had first in his career maintained a symbolic approach, a perspective based on "schemata" or mental structures organizing knowledge and believes according to which students need to apprehend the right facts, rules and believes needed in life and then apply them adequately (Bruner, 1973). However, when faced with new learning contexts and the fact that some children were not achieving as expected according to this perspective Bruner as many others shifted to an approach which puts the focusing on community, interaction and dialogue. He developed this shift in his theory in his work The Culture of Education (Bruner, 1996), where he shows the essential role of interaction and intersubjectivity in the process of learning and transmission of culture. As he puts it "where human beings are concerned, learning (whatever else it may be) is an interactive process in which people learn from each other, and not just by showing and telling" ( $p$. 22).

In line with the centrality of dialogue and the study of interaction in Freire's work, Bruner (1996) includes the reflection and analysis of how teaching and learning are influenced by intersubjectivity, with the child as an "active, intentional being; with knowledge as "manmade" rather than simply there; with how our knowledge about the world and about each other gets constructed and negotiated with others, both contemporaries and those long departed" (p. 65). Rejecting a model in which the teacher is the only one transmitting information, he identified the need to reorganize schools and their cultures in a way such as that facilitates interaction, dialogue and particularly mutual learning. In such school cultures, being naturally good at something directly implies helping others to improve in that same ability and this can be done through his proposal of the creation of sub-communities of mutual learners scaffolding each-other, helping each-other in the learning process according to their abilities (p. 21). The proposal of Bruner sees the authority of the teacher not as a sole transmitter but as the facilitator of interaction and mutual learning among students, with multiple ways of organizing the practice. 
Bruner imagines too the impact that a reorganization of the school cultures and classrooms according to the goal of mutually helping each-other could have an impact on improving our relations in society as well as on the way we conceive culture. As in Freire and as in other educational and social theorists, hope for a better world underlies and inspires knowledge development.

\section{The Dialogical Action and Dialogic Learning: the Impact in the Learning Communities}

Another important impact of the contributions of Freire is to be found on the grounds of the theoretical conceptualization of dialogic learning (Flecha, 2000) grounded on research about how egalitarian dialogue - based on validity claims and not on power claims-, allows for important advances in learning. We have seen the centrality of dialogue between educator and students in Freire and how this dialogical relationship is indispensable to knowledge, understanding it not just as a method or educational strategy but rather as a sort of relationship that promotes the student's drive to learn. Following this, dialogic learning builds on the dialogic nature of humans and the interaction enabled through a dialogue free from imposition or manipulation. This conceptualization of learning thus seeks to promote the conditions for dialogue and the study of all the interactions that children have with people in their community (Aubert et al., 2008).

To do so, dialogic learning makes a difference between dialogic interactions and power interactions (Searle, Soler and Castro, 2004). The former, are based on equality, their aim is to reach the understanding of all speakers involved in the dialogue, and the arguments given are valued according to the contribution they make to the dialogue and not based on the position of power of the person who makes them. The latter on the contrary, are based on the physical or symbolic violence generated by an existing unequal social structure. In the case of a learning context like a school, the social structure ascribes a position of power in decision-making to educators over students as well as over families so that, to a certain extent, their interactions are power-mediated. However, as Aubert et al. (2008) show the fact that the interactions between these different profiles of people are given in the frame of an unequal social structure does not determine their relation. 
There are large differences between types of relations among these agents according, among other factors, to the educational project that is followed in a school and the ethos this project promotes.Therefore, it is one of the main tasks of educators - as we have seen in the above- to create the necessary conditions for interactions to facilitate dialogue, as the sort of dialogical action which leads students to increased learning, unveiling the truth in collaboration with the others and with them and the world.

Following the premises from dialogic learning, research has shown that certain educational actions which are collected in the frame of the Learning Communities project ${ }^{2}$, facilitate that some of the power interactions -such as, for instance, between teachers and student's families- be replaced by dialogical interactions with the result of an improvement on students' educational performance (Flecha, 2014). To do so, the learning communities project departs from the very awareness of the existing unequal social structures and the role they play in the relation between different agents in society. Therefore, efforts are done to create learning contexts in which dialogue is central and which facilitate more egalitarian interactions among the whole school's community - including teachers, students, families and other members- in order to reduce the impact of the power structure in their relations and improve all students' learning. In so doing, the dialogical action is facilitated by reducing the power relations that as a form of symbolic violence distort communication and the possibility of a true dialogue that focuses on promoting understanding and liberation. These new dialogue spaces aiming at facilitating participation because "when families take part in learning interactions they create the conditions for learningrelated dialogue" (Flecha and Soler, 2013, p. 463). Some of these contexts are related to learning processes such as the Interactive Groups of the Dialogic Literary Gatherings and others concern decision-making processes such as the Mixed Commissions and in all of them dialogue and the conditions in which this occurs is an essential element.

The Interactive Groups are a form of organizing the classroom work according to dialogic learning, where small groups are created with students of heterogeneous profiles and where different adults provide guidance and support to each of these groups following the indications of the teacher (Valls and Kyriakides, 2013). These adults are members of the school community that take part as volunteers to encourage supportive interactions 


\section{Ramis - Freire's Dialogic Education}

that increase learning and group's success is the result of everyone's work and commitment. These groups are like Bruner's suggested subcommunities of mutual learners that go one step beyond by facilitating the dialogue not only of the very learners but of them and other members of the community where adults play the role of drivers of the communicative interactions between students in order to guarantee that dialogue promotes the joint creation of knowledge and that all students involved are learning, leaving no one behind (Elboj and Niemela, 2010).

In the domain of decision-making, the learning communities project promote the creation of the Mixed Committees. These are decision-making bodies in which all groups of the school community have a say and a right to decide including families, students, other community representatives as well as teachers and other school staff. They frequency they meet or the topics they jointly decide upon might be different: from deciding on priorities about school's infrastructure, to the organization of the student's educative support, among other issues (Flecha, 2014). Most importantly, in order to facilitate the participation of all agents in these committees, all voices are agreed to have the same value regardless of their role in the school, again placing the focus on the centrality of dialogue and the impact it has in improving the learning process and empowering participants (Diez et al. 2011).

\section{Dialogic Literary Gatherings}

Finally, the Dialogic Literary Gatherings are one of the educational actions building on Freire's contributions and on the principles of dialogic learningis being acknowledged for making outstanding improvements' in people's lives (Flecha, 2014) creating possibilities of better futures for children and adults. Dialogic Literary Gatherings have trespassed the walls of the schools and are being developed in different contexts with a wide array of people. Through bringing participants closer to universal classical literature they are having an impact not only for the impact on improving school student's learning outcomes (De Botton, Girbés, Ruiz and Tellado, 2014) but also for their impact on the emotional wellbeing of children in care (Garcia, Gairal, Munté and Plaja, 2018) or the transformative potential for social insertion of 
prison inmates through solidarity and meaning creation (Álvarez, GarcíaCarrión, Puigvert, Pulido and Schubert, 2018).

This transformative educational practice consists of collectively building knowledge and meaning on the best literary creations of humanity through dialogue and they have been developed to share knowledge among all participants on equal terms. Still, in dialogic literary gatherings the knowledge that one or another participant has about the literary work being read is not important. Rather, it is the exchange among all participants of the meaning about what is being read which creates new knowledge and has shown to have a power of transformation. In the Dialogic Literary Gatherings, the goal is to jointly unveil the world, in Freire's terms, by exchanging the meanings that a certain work has for all participants following the 7 principles of dialogic learning, as we see below.

Dialogic literary gatherings are developed on the basis of an egalitarian dialogue which is based on the conditions for dialogical action as Freire indicated where no coercion, manipulation or power interactions are possible. Therefore, in the gatherings, a person -who might be a teacher, a volunteer, or another reference person- coordinates the session facilitating the conditions for this dialogue, ensuring that everyone is able to participate, and that all are exchanging meanings about what is read and what is being shared.

The cultural intelligence of all members of a diverse community is necessary to succeed in present societies and needs to be included in our schools and classrooms. For instance, by incorporating the knowledge that a Roma person of respect has about her community and the values they cherish about respect to older people, not only do enable to read a world which is part of this diverse community but unknown to many; we also facilitate that all children in our classroom - Roma and non-Roma- comply with this norm of respect to elders. Following Freire, a conversation as educators with cultural communities different than ours which does not seek a shared understanding is not dialogical action. As the creator of the DLGs explains, the knowledge and contributions of an Roma woman about Lorca's the Gypsy Ballads, are very different from other interpretations or insights that might be found on academic books or other literary circles (Flecha, 2000). 


\section{Ramis - Freire's Dialogic Education}

The transformation achieved with Dialogic Literary Gatherings on the lives of migrant mothers in a deprived neighbourhood goes beyond themselves, to reach their homes and the interactions with their own children, increasing both mothers' and children's motivation to read and improving language acquisition, and their children's school performance. In DLG developed throughout many years in prisons for instance, inmates explain how the very change of expectations that their participation in the gatherings provoked in their environment, transformed their own: "when someone changes his or her look on upon you, you change your own look upon yourself"3 (Flecha, García and Gómez, 2013, p.149).

It is well known that constructivist theories that adapt learning to each child's alleged capacity (based on what he or she already knows) such as Ausubel's (1968) have promoted exclusionary educational practices that contribute to reproducing social inequalities and promoted school failure particularly of the most vulnerable children coming from deprived backgrounds. The instrumental dimension in dialogic learning on the contrary focuses on providing the most relevant learning content, including the reading of the highest cultural and literary works of humanity for all children, regardless their learning background. Participants in DLG receive the knowledge of the best works of classical literature but also of the interpretations that all of them make according not only to what they know but to what they share and imagine through their interactions.

As Freire states in his work (2005) meaning creation is a basic feature of true learning, and it can only be accomplished through communication, in a way that "the teacher cannot think for her students (...) thought has meaning only when generated by action upon the world, the subordination of students to teachers becomes impossible" (p.77). Also, in DLG, meaning is created when participants confirm that their view and insights are considered in equal terms as others' and through the very fact of realizing that in so doing not only increased learning is achieved but also higher expectations and motivation for achieving together. DLG have seen for instance, children in complex situations like foster care experiences develope feelings of belonging with a very positive impact on their emotional wellbeing (Garcia, Gairal, Munté and Plaja, 2018).

It is through the solidarity by which all participants share their insights and their knowledge about what is being read that learning and 
transformation occur in DLG because, as Freire puts it, dialoguers need to engage in true dialogue and critical thinking which is based on the solidarity and not imposing one's ideas, and this solidarity seeks the success of all participants, without exception. In DLG the contribution from a Muslim mother who hardly speaks the language of the host society is equally valued as that of a university student volunteer or an illiterate young mother from the neighbourhood. Their diversity of backgrounds, meanings, knowledge and experiences are cherished and bring richness to the learning, following the last of the principles of dialogic learning which is present in the developing of DLG: the equality of differences. This concept entails that the more diverse and rich the interactions, the better for the learning. Through including difference - of cultures, abilities, gender, religions, among other dimensions- in equal terms, and maximizing the diversity of interactions, the learning is maximized at the same time that the opportunity is given for participants to break possible preconceptions and cultural biases.

\section{Concluding Remarks}

Our review of some of the work of the most important educator in the 20th century and one of the most relevant social scientists of all times have allowed to highlight once more the relevance of his contributions and in particular the impact that it had for the development of other theories and practices, both in education and in other social sciences.

Freire was not only a committed educator, but he was also a pioneer social scientist ahead of his time with his Pedagogy of the Oppressed, where he developed a theory that gave dialogue a central role in education and in life, well before other authors did, such as Jürgen Habermas, one of the world's leading thinkers who did so 12 years later. Freire's work brought to the oppressed to the fore, not only proclaiming the need to give voice to those who did not have it but most importantly, developing a theory that enabled educators around the world to contribute to do so. Some of them changed their educational conceptions following the premises of the Brazilian author and contributed to expand the relevance of interactions in amount and diversity, for the sake of a more just and efficient education. Others continued their work with the most deprived peoples and had in Freire's work on the dialogical action a theoretical conceptualization to be 
further developed and to function as a frame for educational actions that create possibilities of transformation of inequalities.

Since Freire's work in 1968, educational actions and theoretical developments building on this work and highlighting the centrality of dialogue and interaction have not ceased to increase. His legacy has provided us with an extremely valuable knowledge about the world and the relevance of solidary interactions to unveil it. And at the same time, his theory has provided the tools that enable all men and women to transform what is being given, creating future and, as he proposed, doing so with an equal need for hope and science.

\section{Notes}

${ }_{1}$ Paulo Freire and Donaldo Macedo, "A Dialogue: Culture, Language, and Race" in Harvard Educational Review, 65(3), fall 1995, p. 379.

${ }^{2}$ The Learning communities is a project that focusing on dialogic learning in all spaces seeks to improve educational performance of school students as well as to improve the situation in their communities both in terms of training needs as well as coexistence levels. More information: https://www.step4seas.org/learning-communities

${ }^{3}$ This quote's translation is the author's.

\section{References}

Álvarez, P., García-Carrión, R., Puigvert, L., Pulido, C., \& Schubert, T. (2018). Beyond the Walls: The Social Reintegration of Prisoners Through the Dialogic Reading of Classic Universal Literature in Prison. International journal of offender therapy and comparative criminology, 62(4), 1043-1061. Doi:

https://doi.org/10.1177/0306624X16672864

Aubert, A., Flecha, A., García, C., Flecha, R., y Racionero, S. (2008).

Aprendizaje dialógico en la sociedad de la información. Barcelona: Hipatia Editorial. 
Ausubel, D.P. (1968). Educational Psychology: A Cognitive View. New York: Holt, Rinehart \& Winston

Botey, J., \& Flecha, R. (1998). Transformar dificultades en posibilidades. Produção de terceiros sobre Paulo Freire; Série Homenagens.

Beck, U., Giddens, A., \& Lash, S. (1994). Reflexive modernization: Politics, tradition and aesthetics in the modern social order. Stanford University Press.

Beck, U., \& Beck-Gernsheim, E. (1995). The normal chaos of love. New Jersey: Wiley-Blackwell.

Bruner, J. (1973). Beyond the information given: Studies in the psychology of knowing. New York: Norton.

Bruner, J. (1996). The culture of education. Cambridge, MA: Harvard University Press.

De Botton, L.; Girbés, S.; Ruiz, L. \& Tellado, I. (2014) Moroccan mothers' involvement in dialogic literary gatherings in a Catalan urban primary school: Increasing educative interactions and improving learning, Improving Schools, 17(3), p. 241-249.

Doi:https://doi.org/10.1177/1365480214556420

Díez, D., Gatt, S., \& Racionero, S. (2011). Placing immigrant and minority family and community members at the school's centre: the role of community participation. European Journal of Education, 46(2), 184-196. Doi: https://doi.org/10.1111/j.1465-3435.2011.01474.x Elboj, C., \& Niemelä, R. (2010). Sub-communities of mutual learners in the classroom: the case of Interactive groups. Revista de psicodidáctica, 15(2). Retrieved from

http://www.ehu.eus/ojs/index.php/psicodidactica/article/view/810

Flecha, R.; Puigvert, L. (1998). Aportaciones de Paulo Freire a la educación y las ciencias sociales. Revista interuniversitaria de formación del profesorado, (33), 21-28.

Flecha, R. (2000): Sharing Words. Theory and Practice of Dialogic Learning. Lanham, M.D: Rowman \& Littlefield, also available in Spanish and Chinese. 


\section{Ramis - Freire's Dialogic Education}

Flecha, R. (2004). La Pedagogía de la Autonomía de Freire y la Educación Democrática de personas adultas. Revista interuniversitaria de formación del profesorado, (50), 27-44.

Flecha, R. (2014). Successful educational actions for inclusion and social cohesion in Europe. Springer.

Flecha, R; García-Carrión, R.; \& Gómez, A. (2013). Transferencia de tertulias literarias dialógicas a instituciones penitenciarias Transfer of Dialogue-based Literary Gatherings to Prisons. Revista de Educación, 360, 140-161.

Flecha, R., \& Soler, M. (2013). Turning difficulties into possibilities: Engaging Roma families and students in school through dialogic learning. Cambridge Journal of Education, 43(4), 451-465. Doi:https://doi.org/10.1080/0305764X.2013.819068

Flecha, R., Soler-Gallart, M., \& Sordé, T. (2015). Social impact: Europe must fund social sciences. Nature, 528(7581), 193. Doi:

https://doi.org/10.1038/528193d

Freire, P. (1997). A la sombra de este árbol. Barcelona: El Roure.

Freire, P. (2005). Pedagogy of the oppressed, $30^{\text {th }}$ Anniversary Edition. New York: Continuum.

Freire, P. (2018). Pedagogy of the oppressed, 50th Anniversary Edition. New York: Bloomsbury Academic

Garcia Yeste, C., Gairal Casadó, R., Munté Pascual, A., \& Plaja Viñas, T. (2018). Dialogic literary gatherings and out-of-home child care: Creation of new meanings through classic literature. Child \& Family Social Work, 23(1), 62-70. Doi:

https://doi.org/10.1111/cfs.12384

Habermas, J. (1984). The theory of communicative action: Vol. 1: Reason and the rationalization of society, trans. T. McCarthy. Boston: Beacon (original work published 1981).

Habermas, J. (1987). The theory of communicative action, volume 2, system and lifeworld: a critique of functionalist reason. Boston: Beacon.

Martínez-Fritscher, Musacchio \& Viarengo (2010). The great leap forward: the political economy of education in Brazil 1889-1930, Harvard 


$$
\text { HSE - Social and Education History, 7(3) } 299
$$

Business School Working Knowledge, 10-075. Retrieved from https://hbswk.hbs.edu/item/the-great-leap-forward-the-politicaleconomy-of-education-in-brazil-1889-1930

Roser, M. \& Ortiz-Ospina, E. (2018) - "Literacy". Published online at OurWorldInData.org. Retrieved from https://ourworldindata.org/literacy' [Online Resource]

Searle, J. R., Soler, M., \& Castro, M. (2004). Lenguaje y ciencias sociales: diálogo entre John Searle y CREA. El Roure.

Soler-Gallart, M. (2017). Achieving social impact: sociology in the public sphere. New York: Springer.

Valls, R. \& Kyriakides, L. (2013). The power of Interactive Groups: how diversity of adults volunteering in classroom groups can promote inclusion and success for children of vulnerable minority ethnic populations. Cambridge Journal of Education, 43(1), 17-3. Doi: https://doi.org/10.1080/0305764X.2012.749213

Maria del Mar Ramis: Universitat de Barcelona (España)

Orcid ID: https://orcid.org/0000-0002-2820-0122

Contact Address: mimarramis@ub.edu 